Chirurgia (2021) 116: 756-768

No. 6, November - December

Copyright@ Celsius

http://dx.doi.org/10.21614/chirurgia.116.6.756

\title{
Intraomental Splenic Implant - An Attempt of Reassessment
}

\author{
Mircea Beuran ${ }^{1 \star}$, Mircea Dan Venter ${ }^{2}$, Dana Paula Venter ${ }^{3}$, Constantin Oprescu' ${ }^{2}$, Sebastian Vâlcea ${ }^{4}$, \\ Tiberiu Georgian Tănase ${ }^{2}$
}

${ }^{1}$ Academy of Medical Sciences, full member

University of Medicine and Pharmacy "Carol Davila", Department of Surgery, Bucharest, Romania

$3^{\text {rd }}$ Department of Surgery, Emergency Hospital Bucharest, Romania

2Department of Surgery, Emergency Clinical Hospital Bucharest, Romania

${ }^{3}$ Division of Pediatric Surgery, $2^{\text {nd }}$ Department of Surgery, Children Emergency Hospital "Grigore Alexandrescu" Bucharest, Romania

"University of Medicine and Pharmacy "Carol Davila", Department of Surgery, Bucharest, Romania

*Corresponding author:

Mircea Beuran, MD

Professor of Surgery

University of Medicine and Pharmacy

"Carol Davila" Bucharest, Romania

E-mail: drmirceabeuran@yahoo.com

\section{Rezumat}

Implantul splenic intraomental - o încercare de reevaluare

Riscul permanent al pacienților splenectomizați la complicații infecțioase, cea mai severă fiind overwhelming post splenectomy infection (OPSI) a determinat căutarea unor soluții care să diminueze aceste posibilități evolutive. Astfel, autotranspantul splenic intraomental pare să fie o opțiune viabilă care, în viziunea unor autori, ar avea efecte benefice prin restabilirea (cel putin parțială) a functiiilor splinei. Articolul prezintă experiența actuală legată de această procedură (principii de tehnică chirurgicală, sediul implantelor, complicații, evaluare postprocedurală) în încercarea de a-l aduce/readuce în atenția chirurgilor de traumă /chirurgie generală. Procedura este simplă, rapidă şi cu complicații minime/absente şi trebuie aplicată după orice splenectomie posttraumatică.

Cuvinte cheie: trauma, splenectomy, splenic implants

\section{Abstract}

The permanent risk of splenectomized patients to infectious complications, the most severe being overwhelming post splenectomy infection (OPSI), determined the search for solutions in order to diminish these evolutionary possibilities. Therefore, intraomental 
splenic autotransplantation seems to be a viable option which, according to some authors, would have beneficial effects by restoring (at least partially) the functions of the spleen. The article presents the current experience related to this procedure (principles of surgical technique, implant location, complications, post-procedural evaluation) in an attempt to bring it back to the attention of trauma / general surgery surgeons. The procedure is simple, fast and with minimal or no complications and should be applied after any post-traumatic splenectomy.

Key words: trauma, splenectomy, splenic implants

\section{Introduction}

Although nonoperative management - NOM (which includes splenic angioembolization) and, in some cases, conservative surgery are common current methods in spleen trauma, there are situations in which splenectomy cannot be avoided.

When splenectomy is needed, splenic autotransplantation is the only method that can preserve splenic function (1).

It has also been called an autologous splenic implant.

Its purpose is to maintain (preserve) the splenic immune role and, consequently, to prevent fulminant post-splenectomy infection.

W. Krivit "early and distant morbidity would be higher if, following the trauma, the intraperitoneal implantation of some fragments from the spleen would not be performed, which performs a heterotopic transplant» (cit. Gorovei)(2).

Griffini and Tizzioni (1883) made the first splenic implants in dogs. In trauma, the procedure was used by Albrecht (1896) and Schilling (1907).

Stubenrauch (1912) describes autotransplantation of splenic fragments into the peritoneal cavity, experimentally in dogs $(3,4)$; the viability of the implanted splenic fragments was demonstrated on examination after slaughter of the animals at 3 months.

Buchbinder and Lipkoff (1939) introduce the term splenosis and in the same year Calder confirms the spontaneous growth of splenic fragments in the abdominal cavity.

The evolution of splenic implants has been suggested by post-traumatic / postoperative splenosis.

The first splenic autotransplant was reported by Zsakarov (Ciacarov?) in 1975 (5).

Gorovei (2) published in 1987 in the Journal of Surgery a case presentation of a child, in which he performed a total splenectomy with heterotopic autotransplantation of the caudal pole of a traumatized spleen in an epiploic "pocket" created near its free edge (which is turned upside down by applying a few nylon threads around the transplanted fragment); Subsequent scintigraphy confirms the morphological integrity of the transplant and its functionality. Earlier, in the country, such cases were reported by Al. Pesamosca and D. Kadar but without morpho-functional scintigraphic evaluation.

\section{Indications for autologous splenic implant}

Indications for autologous splenic implant (6-11) are:

- splenic traumas in which total/partial preservation cannot be achieved (grade 4, 5 lesions);

- Gaucher disease;

- myeloid metaplasia (caused by idiopathic myelo-fibrosis);

- chronic lymphocytic leukemia and schistosomal portal hypertension. Basically, all cases in which total splenectomy should be performed.

Contraindications to the splenic implant $(5,7,12)$ are:

- simultaneous entero-colonic lesion (the relatively devascularized splenic fragment would be a place for the develop- 
ment of septic complications). In Moore's opinion [cit. Pisters (7)], simultaneous peritoneal contamination is not a contraindication to the splenic implant;

- advanced age;

- damage control laparotomy;

- the surgeon's preference (?).

\section{The location (place) of the implant}

According to most authors, the optimal location of the implant is represented by the great omentum $(4,7-9,11,13,14)$. The considerations of this option are represented by:

- a rich vascularization that allows the increased intake of growth factors, cytokines and inflammatory cells; the vascularization of the great omentum ensures the ideal conditions for the diffusion nutrition of the implant ("per diffusionem") in the stages of regeneration and neovascularization (13). Drainage in the portal shaft enhances graft functions (15).

- hepatopetal blood drainage through the port system (normal drainage of the orthotopic spleen);

- increased rate of bacterial clearance $(16,17)$

However, the reality is not precisely known (7) and it is not possible to state a superior regeneration of the implanted splenic fragments and their functions when they are placed omental.

Boland [cit. Şeicaru (18)] presents a case in which the autopsy (performed for another cause) in a patient with heterotopic splenic autotransplant found significant hypertrophy of the splenic tissue fixed in the large omentum considering this graft site optimal.

Other locations used (in the absence of the great omentum) were:

- subfascial properitoneal (19);

- mesocolon (9);

- muscular;

- between the sheets of the mesentery (5);

- retroperitoneal;

- subcutaneous (outlawed).

Splenic tissue transplanted into an extraperitoneal space does not satisfactorily eliminate Streptococcus Pneumoniae and, consequently, does not prevent infections (Patel, Horton cit. Weber [13]). Muscular / subcutaneous implantation ensures the viability of the fragments but these, from a functional point of view, are insufficient [Alvarez 1987, Clayer 1994 cit. Teixeira (20)].

\section{Amount of splenic tissue implanted $(4,7,8,11)$}

Studies by Patel (1982), Holdsworth (1991), Iinuma (1992), Resende (2002) (10) have suggested that $25 \%$ of normal, orthotopic and vascularized splenic tissue is sufficient to maintain complete splenic function. It is equivalent, in humans, to 35 grams (10).

Ionescu's opinion (5) is that $1 / 2-1 / 3$ of the entire splenic parenchyma should be used for grafting.

Weber (13) considers a quantity of 50 grams of the original spleen necessary to ensure complete function.

Experimental animal studies have suggested that reimplantation of $25-50 \%$ of the splenic volume provides improved phagocytic function and pneumococcal protection (21).

\section{Implant evolution $(3,4,9,12,13)$}

There are 3 stages: necrosis, regeneration and development of vascularization.

Some authors have stated the increase in implant size over time. Holdsworth (cit. 9) considers that the splenic implants return to the normal tissue structure and partially resume their function about 3 months after the operation, passing through the mentioned stages during this period. Regeneration of the splenic implant is more pronounced in young people (5).

From an evolutionary point of view, the implant initially presents a central necrosis (12) followed by regeneration and increase in size, presenting the identical splenic structure at 5 weeks after the procedure.

Tavassoli (1973) found, experimentally in mice, that regeneration begins with the formation of large spaces at the periphery of the implant, called by Velle (1988) vascular spaces. These histological changes are dependent on the local blood supply of the 
implant (Seufert, Mitrou 1986, Johnson and Weiss 1989). This implant regeneration has been described using electron microscopy by Sasaki (1991) [cit. Alves (3)].

Until the appearance of vascular anastomoses, the implants have the vascularization secured by the neighboring tissues (3). Alves (3) found experimentally, by injecting fluorescent polystyrene microspheres into the orbital plexus in mice with splenic implants (in the gastrolienal ligament, mesocolon and perirenal fat), their presence at the periphery of the implants (at the earliest 3 days postoperatively). The concentration of microspheres increases over time being highlighted more deeply in the splenic parenchyma; at 10 weeks postimplantation the marginal area is absent or rudimentary (Lau and Ong, 1983). The presence of microspheres initially at the periphery of the implant and later deep in the splenic parenchyma indicates that their revascularization develops centripetally; the anastomoses between the vessels adjacent to the implant and of the implant itself are performed starting from the $3^{\text {rd }}$ day (3).

Only one study [Bradsh cit. Ionescu (5)] showed that "autotransplant regeneration is inhibited by spleen fragments left in place".

The biological activation of the splenic autotransplant occurs starting from the 15th postoperative day, the almost complete replacement of the splenic functions being achieved on average at 3 months (5). Phagocytosis of Gram-negative bacteria not encapsulated by autogenic splenic implants has not been evaluated (22).

The experimental study of Marques and Petroianu (22) demonstrated the regeneration of splenic autotransplantation at 16 weeks postoperatively, the splenic tissue presenting white pulp, red pulp, lymphatic follicles and the marginal area with moderate changes; the blood vessels showed intact walls, without signs of vasculitis / thrombosis.

\section{Surgical Techniques}

The following surgical techniques for heterotopic splenic autotransplantation are described:
- splenic microfragmentation technique ("splenic omelet procedure"-splenic homogenate);

Lucas (23): the excised spleen is sectioned into multiple fragments with a maximum size of $2 \mathrm{~mm}$; the amount used is $50 \%$ of the splenic mass and is placed in omental pockets made by rolling the large omentum and fixing with absorbable threads.

- Gorovei (2) takes the splenic caudal pole which he implants in a pocket created near the free edge of the large omentum which is cranially overturned, applying a few nylon threads around the splenic fragment: Romanian priority?

- Moore technique uses 5 splenic fragments with dimensions 40x40x3 mm placed in pockets made in the large omentum and possibly marked with metal clips (to facilitate paraclinical follow-up).

Moore [cit. Weber (13)] demonstrated a low complication rate in 43 patients compared to other splenic rescue methods; did not show complications related to the splenic implant.

- Ionescu technique (5)

uses fragments of $30 / 10 / 5 \mathrm{~mm}$, decapsulated (15) implanted in "small pockets formed in the folds of the large omentum". Subsequently, the author returned to the dimensions of 20/25/5 $\mathrm{mm}$, decapsulated. Decapsulation facilitates revascularization and readaptation of implanted splenic fragments (Seufert cit. Ionescu [15]).

- Petroianu technique

is currently used in the Emergency Clinical Hospital (will be detailed in the next paragraph). Uses 20 splenic fragments with the following characteristics: size $=1-2 \mathrm{~cm}$, weight $=2-4 \mathrm{~g} /$ fragment. The total weight of the implanted fragments is $\geq 50$ grams. These are sutured on the outer face of the large omentum strung on a 3-0 catgut thread (original technique) in the shape of the letter S; A Vicryl 3-0 yarn is used in the clinic. The great omentum folds over these fragments so as not to come into direct contact with the anterior parietal peritoneum.

- Di Carlo technique (16)

is the most recent. After the splenectomy, the organ is weighed and a $4 \times 3 \times 2 \mathrm{~cm}$ fragment 
weighing $35 \mathrm{~g}$ is prepared from the whole part (the fragment is obtained through the cross section of the spleen). A vascularized left epiploic flap is prepared and the harvested splenic fragment is implanted in an epiploic "pocket" created at this level. Finally, this epiploic fragment is fixed at the level of the posterior parietal peritoneum of the left upper abdominal quadrant.

The number, weight and size of splenic fragments was established following a protocol based on literature studies (Pisters, Pachter, Zoli, Iinuma, Thalhamer, Holdsworth, Feigenberg) and the author's studies (Petroianu, Marques, Vidigal, Resende).

\section{Technique Used in Bucharest Emergency Clinical Hospital for Heterotopic Splenic Implant}

The heterotopic splenic implant was performed inconsistently. Starting with 2005, it was performed using the technique of Prof. Dr. Petroianu. The average duration of the procedure is 10 minutes, being practically indicated in all cases of total splenectomy (except for lesion control surgery). The technique used is as follows:

- 20 splenic fragments with dimensions of 1-2 $\mathrm{cm}$ are obtained (Fig. I) (in which the capsule is extracted - this allows intimate contact of the fragments with the receptor area and promotes angiogenesis). The weight of a fragment is $2-4 \mathrm{~g}$.

- The fragments are introduced into saline serum.

- The great omentum is displayed and a damp compress is applied to its anterior face.

- The splenic fragments are fixed omentally by a simple suture with Vycril 3-0 or 4-0 (splenic fragment - oment - splenic fragment - oment...) achieving the appearance of the letter S (Fig. 2).

- The omentum is rolled over the splenic fragments (without suture) to prevent adhesions to the anterior parietal peritoneum.

The omental suture is not necessary due to

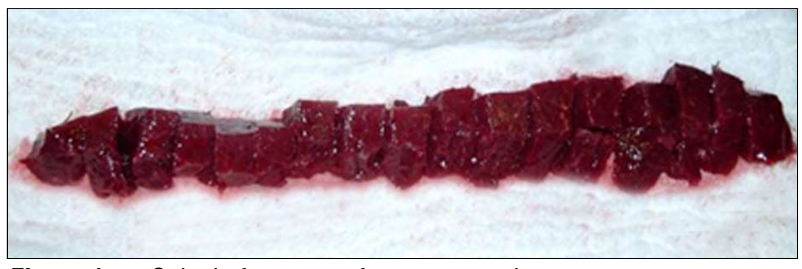

Figure 1. Splenic fragments for autotransplant

(published with the consent of Prof. Dr. A. Petroianu)

the fact that at 24 hours, when the patient can be mobilized, the epiploono-parietal adhesions are formed.

The photos used to describe the procedure were kindly published by Prof. Dr. Andy Petroianu (UFMG Belo Horizonte, Brazil).

The characteristic of this technique is simplicity; to this is added the speed of execution, the operative time being extended by about 10 minutes (while the operator performs a last control of hemostasis and institutes the peritoneal drainage, the auxiliary assistance prepares the splenic fragments that will be implanted).

Cothren (12) conducted a study of the CT appearance and evolution of splenic implants. Thus, early CT examination reveals multiple intra-abdominal fluid collections that may be similar to abscesses; their percutaneous drainage was sterile creating a diagnostic dilemma. The author followed the CT characteristics of the implants, their modification over time and the possibility of differentiating them from intraperitoneal abscesses. The

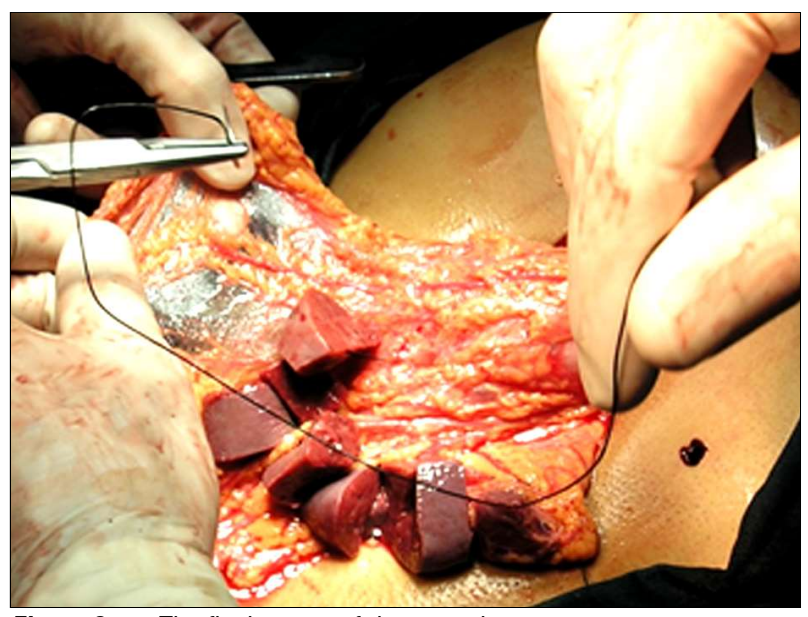

Figure 2. The final aspect of the procedure (published with the consent of Prof. Dr. A. Petroianu) 
findings were as follows:

- day 9: fluid collections, without adjacent inflammatory phenomena;

- day 14: shrinking the implant with its peripheral load; lack of inflammatory phenomena around the implant.

- day 52; the absence of inflammatory phenomena around fluid collections; reducing the size of the implant (by 50\%) and the peripheral load.

- day 113: reduction of the splenic implant by another $20 \%$ (from $5 \mathrm{~cm}$ to $2.1 \mathrm{~cm}$ ); absence of inflammatory changes; the persistence of the peripheral load which is greatly diminished.

The presence of gas bubbles in the implants, adjacent inflammatory changes and increased peripheral load suggest infection / abscess of the implant.

The recognition of these tomographic aspects allows the differentiation between the splenic implant, the infected splenic implant and the intra-abdominal abscess, eliminating a possible non-therapeutic intervention.

\section{Complications $(7,8,11,12,13,14,16,24,25)$}

In Surendran's review (21), postoperative complications were found in $3.7 \%$ of cases, with $1.3 \%$ of patients having postoperative infections. It is still unclear whether these complications are directly related to the splenic implant or can be classified as general surgical complications (21).

Rhodes-1988 [cit. Lucas (23)] describes an omental abscess that appeared after the "splenic omelet procedure" (in a patient who had a distal pancreatectomy and splenectomy for a pancreatic pseudocyst) for which he was reoperated on day 11 postoperatively. The author suggested that coagulation necrosis is a fragile period, with increased susceptibility to infection and a contraindication to peritoneal contamination.

Complications of the procedure are rare (2-3\%) (13); Petroianu $(10,11)$ did not report any complications. Similarly, Toro (25) claims the absence of post-procedural complications by the Di Carlo technique. Described:

\section{Early complications}

- subphrenic abscess (16) secondary to implant necrosis;

- abscess of the implanted fragment,

4 published cases; 1 case after extraperitoneal splenic implant and 3 cases after epiploic implant, one being secondary to the splenic microfragmentation technique.

- aseptic necrosis (24)

occurs more frequently in conditions of perioperative shock secondary to decreased omental microcirculation.

\section{Late complications}

- tortion of implants,

- intestinal occlusion,

2 cases were published (12); occlusion was secondary to adhesions around an implant abscess.

- chronic anemia $(16,25)$,

- posttraumatic hemorrhage by rupture of implants that are no longer protected by the costal rim (16).

\section{Implant Evaluation}

The functionality of splenic implants is evident 1-3 months after splenectomy secondary to trauma (26), at least 2 factors being important: the volume of the implanted splenic tissue and the efficient local vascularization.

The viability and functions of the implants are evaluated at 3 months postoperatively $(9,12,24)$ :

\section{- viability}

By scintigraphy with heat denatured erythrocytes marked with Tc99m (of choice for implant evaluation); Quantitative evaluation can also be performed by scintigraphy with Tc99m colloid sulfur (12), but has a limited value, spleen receiving only $10-15 \%$ of the injected dose of radioactive substance. The mere presence of splenic tissue demonstrated scintigraphically does not imply normal immune function. In early scintigraphy (at 1-2 weeks postoperatively) the splenic implants are difficult to visualize presenting a lower radioactivity than the liver; in the case of 
evaluation scintigraphy (at 3-5 months) the intensity of the tracer accumulation is significantly increased (Fig. 3) (27).

Fixation / sequestration in the graft of platelets marked with isotopes has a high functional value being similar to that of the normal spleen.

- CT scan (Fig. 4A,B)

Splenic implants at 9 months: multiple splenic implants with a maximum diameter of $25 \mathrm{~mm}$, homogeneously opacified, located in the large omentum (collection of Dr. Chiotoroiu).

Scintigraphy combined with CT examination allows the evaluation of filtration function and reimplanted splenic volume in a single investigation (21).

Recently Weber (13) reports the possibility of measuring implant dimensions by using SPECT (Single-Photon Emission Computed Tomography) performing a quantitative determination (allows determining the volume of each implant).

- Ultrasound highlights hypoechoic formations, located at a short distance from the antero-lateral abdominal wall, at the level of the great omentum (Fig. $5 \mathrm{~A}, \mathrm{~B}$ ).

Doppler ultrasound can demonstrate the neovascularization of implanted splenic fragments (Fig. 6 A, B):

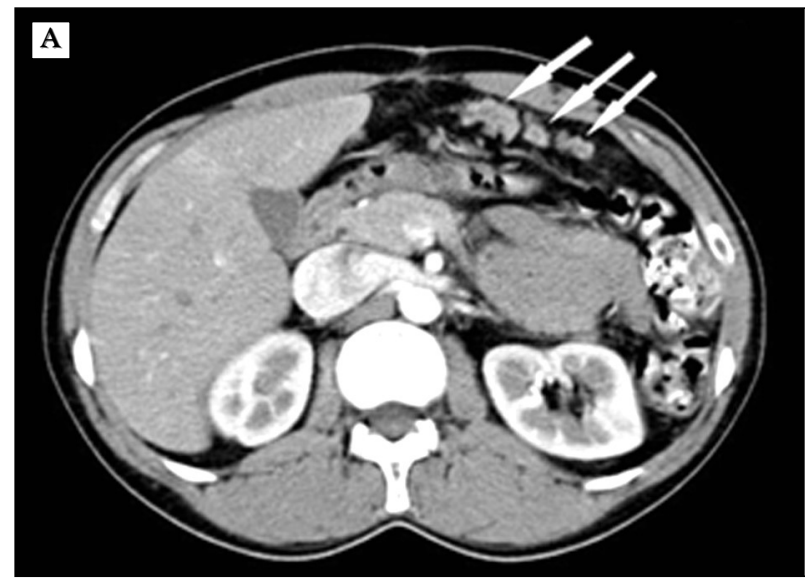

Figure 4. (A) Splenic implants - CT appearance at 9 months postprocedurally (contrast-enhanced axial image). (B) Splenic impants - CT appearance at 9 months postprocedurally (contrast-enhanced coronal image).

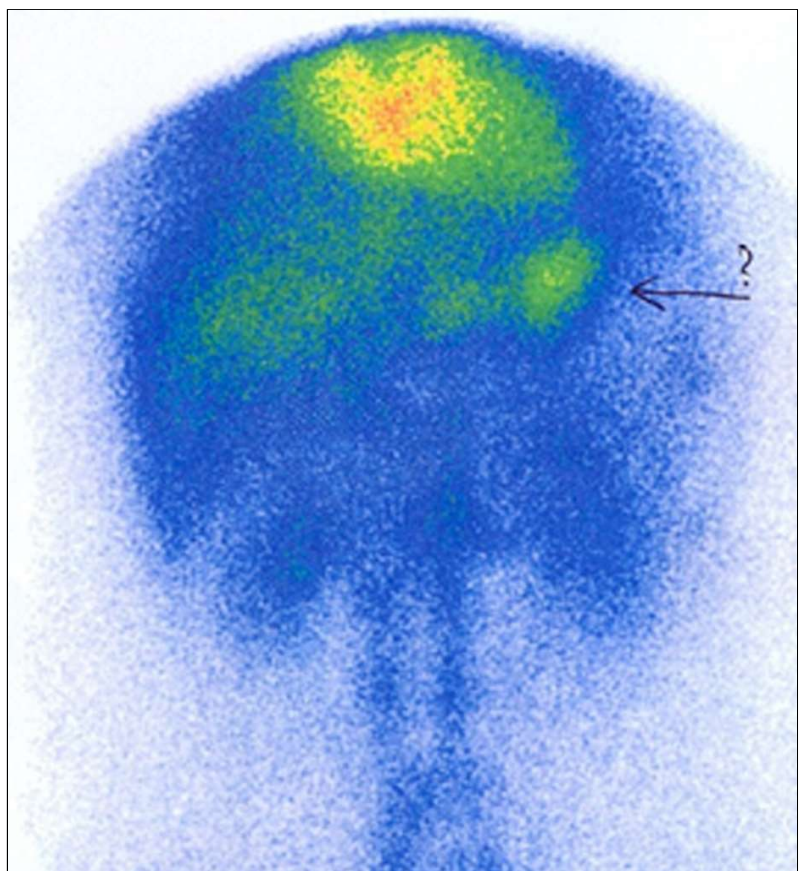

Figure 3. Splenic implants (scintigraphic aspect)

- Doppler ultrasound with contrast agent SONO VUE increases the quality of the image ofthe vascularization of the splenic implants (Fig. T).

- filtering function.

Disappearance of Howell-Jolly bodies (peripheral smear, Giemsa staining), platelet count.

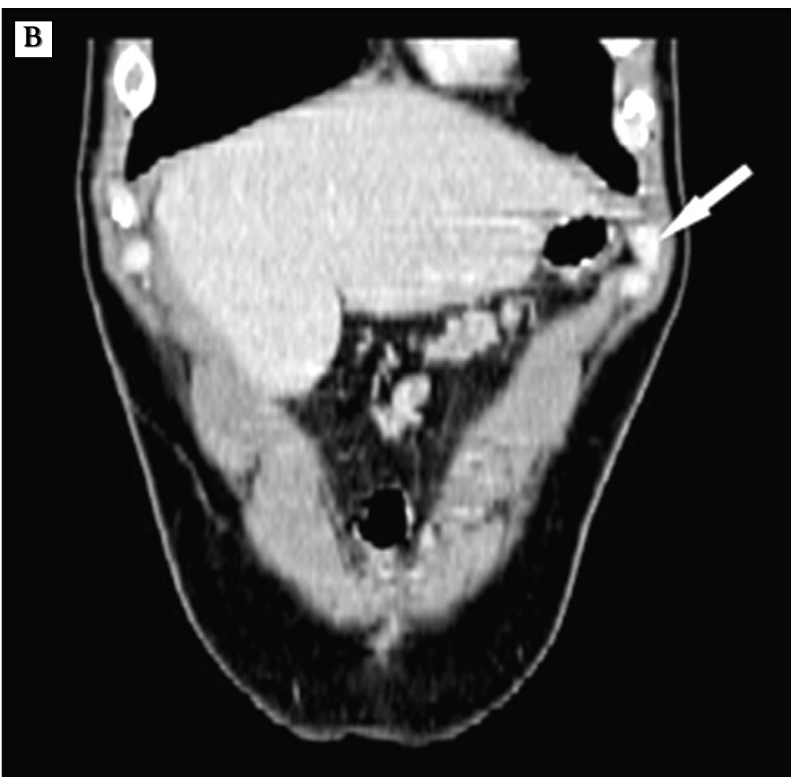



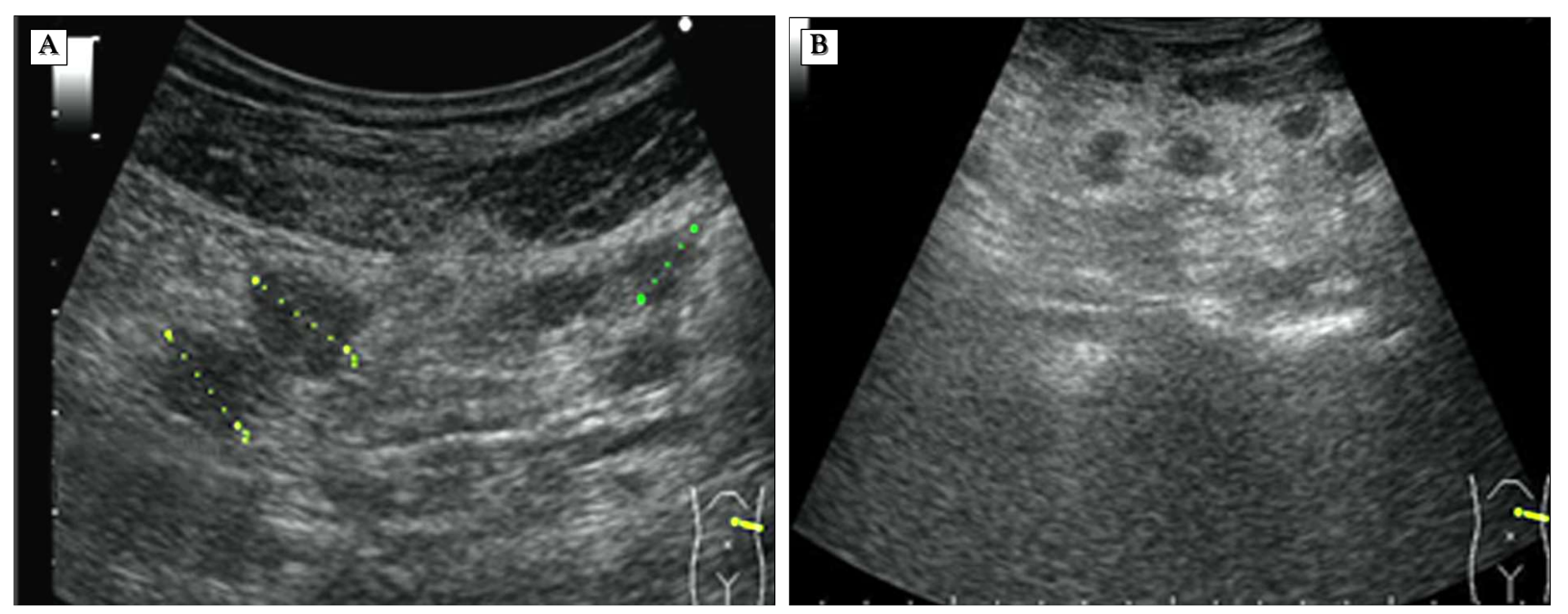

Figure 5. (A, B) Intra-omental splenic implants - ultrasonographic aspect

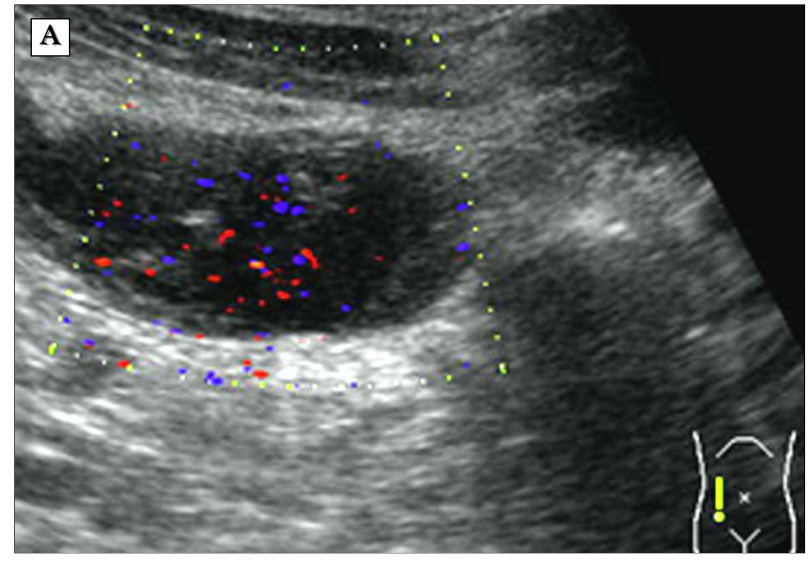

Micronuclear reticulocytes (MN-RET) with normal number (25) (biomarker of hemocathesis), determined by flow-cytometry

Complete blood count:

- phagocytic and immunological function

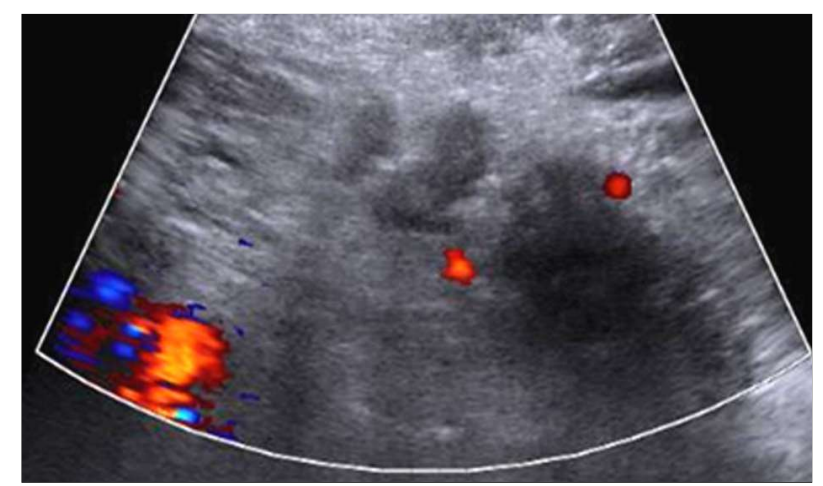

Figure 7. Doppler ultrasonography with Sono Vue contrast agent (Dr. Chiotoroiu's collection)

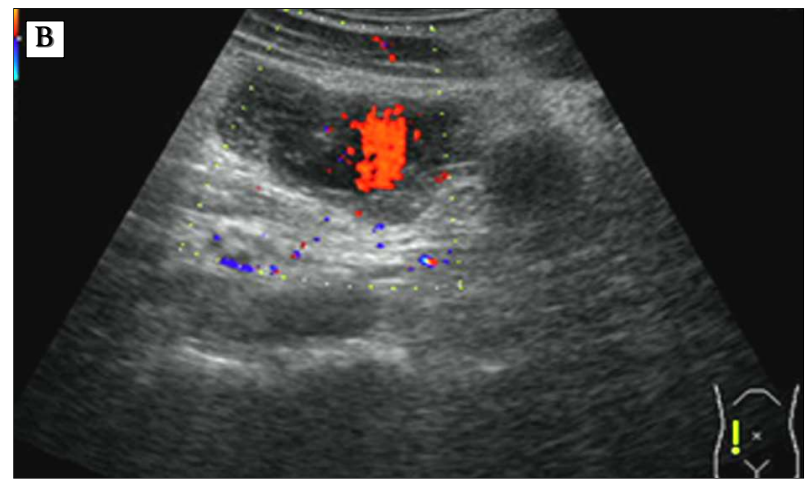

Figure 6. (A, B) Doppler appearance of splenic implants

- determination of tuftsin level (by ELISA), IgM level (normalization), IgA, IgG NBT test (evaluates the phagocytic function of granulocytes);

- determination of CD3, CD4, CD8, CD4 / CD8-, CD19 in the peripheral blood (shows low values in the first week postoperatively normalizing at 3 months postoperatively);

- serum complement level (C3-C4);

- B lymphocytes show increased values after implantation $(13,14)$;

- determination of titer of anti-pneumococcal antibodies (ELISA).

Tuftsin (endocarboxypeptidase) is produced only by the spleen; shows a significant correlation with residual splenosis secondary to post-traumatic splenectomy (14).

At 6 months postoperatively the evaluation 
will include the determinations $(11,12)$ :

- Howell-Jolly bodies;

- poikilocytes;

- thrombocytosis.

which disappear 4 weeks after the splenic implant.

Evaluation of the immune response (implant functionality):

- $\uparrow$ bacterial clearance;

- $\uparrow$ antipneumococcal antibodies;

- $\uparrow$ Ig M;

- $\uparrow$ tuftsin;

- $\uparrow$ phagocyte oxidative burst.

Blood count, peripheral blood smear analysis (readily available and low cost tests) (28), IgM determination and scintigraphic examination are usually used.

According to Ionescu (29), the hematological and immunological function of splenic implants is restored between days 15-19 postoperatively (demonstrated hematologically, immunologically, ultrasound and scintigraphic function).

Patel and Williams [cit. Weber (13)] performed the splenic autotransplant using 20 $\mathrm{g}$ of splenic tissue placed in a preformed bag at the level of the large omentum and followed its evolution by:

- hematological examinations

- Howell-Jolly bodies (disappeared at 4 weeks);

- platelets have normalized;

- Ig M (initially low) normalized;

- scintigraphic

at 8 weeks the presence of functional splenic tissue was confirmed.

The implantation site option was the great omentum (drains venous blood into the port system).

The only prospective study on intraomental splenic autotransplantation belongs to Khorshidi (30).

The author found at

- 3 months postoperatively:

- significant increase in erythrocyte, hemoglobin, hematocrit and lymphocyte levels;

- presence of Howell-Jolly bodies (26.3\% in each field);

- 6 months postoperatively:
- the increase of the values of these elements was not significant;

- significant increase in splenic phagocytic function;

- significant reduction of Howell-Jolly bodies (15.8\% in each field).

The other blood elements did not show significant changes at 3 and 6 months, respectively.

Phagocytic function of splenic implants is not restored early postoperatively due to the inflammatory response (30).

\section{Controversies}

\section{The autologous splenic implant has no function}

It is the opinion of the following authors: Pabst, Ludtke, Thalhamer, Malangoni, Lanng Nielsen, Timens $(31,32)$.

Even if the preservation of the optimal amount of implanted splenic tissue (the so-called "critical mass") and the decapsulation of the splenic fragments are essential measures for the prevention of their extensive necrosis, they do not guarantee a favorable evolution; it is unlikely that the splenic blood flow-specific effect will be achieved in autotransplant cases (24).

In fact, the role of splenic implants in terms of body protection, metabolism or hematological function has not been clearly demonstrated. The decision to perform the splenic implant must be left to the surgeon as the results of the method are not clear (6).

\section{The autologous splenic implant has} important and well-specified functions

Experimental studies have described: low sepsis of animals with splenic implants vs. asplenic control groups [Marques (22), Cooney (33), Holdsworth (34), Willfuhr (35)].

o animals with splenic implants presented infections more frequently than the control groups (with intact spleen) or those in which a partial or subtotal splenectomy was performed [Petroianu (36)];

$o$ the absence of abnormal particles in the 
peripheral smear, the positive scintigraphic image, the increased level of Ig, especially IgM (usually produced by the spleen) suggest the functionality of the implants $(4,10,22)$;

o after the intraomental splenic implant the clearance for Streptococcus Pneumoniae is maintained at $50 \%$ while after the splenectomy no bacteria is eliminated (Patel cit.13).

In 1982 Bauer (37) reported two cases of splenic rupture secondary to trauma that occurred during birth resolved by splenectomy. One case benefited from a splenic implant and the second from penicillin prophylaxis. The evolution of the last case was complicated by candidal meningitis.

Weber's analysis (13) found:

- 1 year after the procedure phagocytosis and proteolysis of implants was similar to that of patients with normal spleen;

- $50 \%$ of the original clearance for Streptococcus Pneumoniae is retained while no bacteria is eliminated in splenectomized patients;

Howell-Jolly bodies and modified erythrocytes may be present in the peripheral blood in splenectomies (the spleen eliminates irregularly shaped erythrocytes and platelets).

The ability to eliminate cellular inclusions is called "pitting" and is an indirect evidence of the presence of splenic tissue. Henneking (38) found that patients with splenic implants with normal filtration function had fewer immunological alterations than the group of autotransplants with increased pitted erythrocytes (a sign of poor implant function).

The reticuloendothelial function of implants (assessed by the elimination of labeled erythrocytes) correlates with the filtration function.

At least 14 cases of OPSI death have been reported in patients with evidence of residual or regenerated splenic tissue; most of these patients had autopsy splenic accessories or splenosis documented $(34,39)$ and 1 death in a patient with intraomental splenic implant [Moore (40)].

Although the information is contradictory, a favorable immunoglobulin response to pneumococcal vaccine in patients with splenic autotransplantation has been reported (41).

\section{Is autologous splenic implant indicated in} $H I V+$ patients with post-traumatic splenic rupture?

In HIV patients, the spleen is the site of viral replication, especially in the asymptomatic phase of the disease, but the splenic implant decreases the risk of opportunistic germ infections and sepsis (42). The author performed a splenic implant secondary to a post-traumatic splenectomy in an HIV + patient, but technically implanted $35 \mathrm{~g}$ of splenic tissue in a single omental "pocket" in order not to give the virus a large replication space, the amount of implanted splenic tissue being sufficient to avoid immunological deficiency.

Experimental studies in mice have shown that one of the targets of HIV is CD27+ B220 ${ }^{-} \mathrm{B}$ cells (similar to human cells in the marginal splenic area), their depletion being parallel to the alteration of the B lymphocyte population, a fact involved in the B lymphocyte immunological insufficiency against the encapsulated bacteria (42).

Therefore, the author maintained splenic immune function and limited the site of viral replication, a useful fact for these patients. Further studies are needed, but we can say that in such situations, the autologous splenic implant is a useful solution, which can not be considered a therapeutic mistake.

\section{Conclusions}

Heterotopic splenic implant:

- is a good option for maintaining spleen function when total splenectomy has been necessary;

- must be performed when removal of the entire splenic tissue is not indicated;

- can partially restore the function of the reticulo-endothelial system;

- intraomental is superior to splenectomy, but obviously inferior to the preservation of the spleen "in situ" (43);

- it is a simple, fast and "reasonable" proce- 
dure [Kusminsky cit. Tzoracoleftherakis (24)] with minimal associated morbidity;

- it is a safe technique that can be performed in the presence of lesions of the cavitary organs;

- allows the clinician the possibility of maintaining the marginal area, essential in the immune response to the aggression of encapsulated bacteria and in the rapid humoral response to blood antigens (44);

- some studies have suggested a possible role of the spleen in lipid metabolism so that splenic autotransplantation may have a protective role in cases with elevated blood lipids (30).

Petroianu's experimental studies (4) showed that in cases with subtotal splenectomy phagocytosis was higher in the first 3 months postoperatively; after this period no differences were reported between the phagocytic function of the implants and the preserved superior splenic pole; splenic autotransplantation is a useful alternative when splenectomy is mandatory (45).

Splenic implants differ from the transplantation of other parenchymal organs (kidney, heart, liver, pancreas, lung) by two elements: they are autogenic and do not require vascular anastomoses [Marques and Petroianu (46)].

Triple vaccination (pneumococcus, Hemophilus influenzae, meningococcus) is strongly indicated after heterotopic splenic autotransplantation. The optimal time to perform is the $14^{\text {th }}$ postoperative day (47).

It must be permanently at risk of forensic implications, especially in the case of major splenic ruptures and intraparenchymal hematomas when, in order to elucidate the causes of mortality, a postmortem CT / angiographic examination is necessary (48).

\section{Recommendation}

"... to keep the spleen as long as possible, because clinical and experimental data have shown that it is better with the whole spleen than with part of it and better with part of it than with nothing. 'Raymond Hinshaw Lcit. Seicaru (18)].

\section{Splenic autotransplantation in children}

Zamfir's study (49), presented at the National Congress of Surgery in 1995, analyzes 220 post-traumatic splenic ruptures analyzed in two periods:

- until 1980 when the splenectomy was performed systematically (139 cases);

- period 1980-1995 (81 cases), when the splenectomy was performed only in severe lesions / associated with rupture of a cavitary organ. 38 splenorrhaphies, 9 partial splenectomies, 1 case of NOM and 33 splenectomies were performed, followed in 10 cases by implantation of splenic fragments at the level of the great omentum or right abdominal muscle.

Starting from the finding that in young children, the ability to produce antibodies is reduced Lee (50) et al. analyzed the role of splenic autotransplantation in cases where splenectomy was unavoidable.

The technique used was:

- after splenectomy, the spleen was inspected to establish the degree of lesion, viability and the presence of a possible pathology;

- section of the spleen into cubic fragments of $1-2 \mathrm{~cm}^{3}$ (depending on the child's weight and the space available at the level of the large omentum);

- 4-5 implants are fixed at the level of the anterior face of the large omentum with non-absorbable wire, after which the free omentum is rolled over them; the great omentum is used due to the favorable revascularization of the implants, the portal drainage and the omental bacterial clearance.

- obligatory vaccination according to current indications.

Complications of the method are:

- precocious aseptic necrosis of implants, intraperitoneal abscesses, intestinal occlusion;

- late overwhelming postsplenectomy infection (OPSI).

The author evaluates the function of splenic autotransplants by: 
- ${ }^{99 m}$ Tc scintigraphy with heat-distorted red blood cells at 6 months postoperatively; demonstrates the viability of splenic implants.

- peripheral blood smear evaluates the absence of Howell-Jolly bodies at 3 months postoperatively;

- cell blood count.

Determines the number of platelets; reactive thrombocytosis is transient and gradually decreases to normal. It is routinely performed in the first year after surgery.

- determination of IgM and serum C3 (complement) values.

Lee's conclusions (50) are:

- splenic implants have a function similar to that of splenosis;

- splenic autotransplant is a safe procedure;

- considering that the risk of OPSI in young children is 6 times higher compared to the average risk of patients between 0-12 years, splenic autotransplant is more beneficial in young children.

The immune response in polytraumatized children shows changes characterized by a hyperinflammatory state (days $2-5$ posttrauma) followed by delayed immunosuppression (with increased susceptibility to infections, sepsis and multiple organic insufficiency); surgery during this period (days 2-5) should be avoided (51).

The discharge recommendations consisted of:

- gradual return to normal activity after 4 weeks;

- prohibiting the practice of competitive sports for at least 6 months.

\section{Final Conclusion}

"Autotransplantation is mandatory under 16 years, optional over this age. It is a method which is worth trying in all the cases indicated, its risks being practically nonexistent and its advantages indisputable. "(5)

It provides undeniable benefits, the technique being simple, atraumatic, fast and reliable in any surgical service (15).

It is a simple, safe procedure (with minimal postoperative complications); it is uncertain whether it provides a degree of protection against OPSI (21).

"Implantation of autologous splenic tissue is an available method, the omission of which is more than a sin: it is a mistake (52)".

\section{Conflict of Interest}

The authors declare no conflicts of interest.

\section{Ethical Statement}

The authors are responsible for all aspects of this study.

\section{Authors' Contributions}

All authors have contributed equally to this article.

\section{References}

1. Di Carlo I, Toro A. Splenic autotransplantation is always valid after splenectomy. J Invest Surg. 2017;30(6):401-402.

2. Gorovei Al. Autotransplantul heterotopic în traumatismele splinei. Rev Chir Oncol, Radiol ORL Oftalmo Stomatol Chir. 1987;36(5);357-358.

3. Alves HJ, Viana G, Magalhăes MM, Arantes R ME, Coelho PMZ, CunhaMelo JR. Kinetics of neovascularisation of splenic autotransplants in mice. J Anat. 1999;195( Pt 3)(Pt 3):387-92.

4. Petroianu A. Avaliaçăo da funçăo fagocitariá em remanescentes de esplenectomia subtotal e auto-implante esplênico autógeno. Rev. Bras. Hematol. Hemoter. 2003:25:25-30.

5. Ionescu NG, Szabó J. Implantul si autotransplantul splenic. În Ionescu NG (coord.) Splina. Cluj-Napoca: Ed. Dacia; 1993. p. 130-142.

6. Martin LW. Autologous splenic transplantation. Editorial. Ann Surg. 1994; 219(3):223-4.

7. Pisters PWT, Pachter LH. Autologous splenic transplantation for splenic trauma. Ann Surg. 1994;219(3):225-35.

8. Petroianu A, Vidigal FM, Costa VC, De Oliveira SC. Splenic autotransplantation in Gaucher's disease. Dig Surg. 2000;17(2):181-3.

9. Haowei Wang, Zengli Liu, Jinchang Wu, Haorong Wu. Value of spleen imaging with 99mTc labeled heat-damaged erythrocytes in evaluating the function of splenic autotransplants. Ann Nucl Med Sci. 2001;14:91-95.

10. Resende V, Petroianu A, Junior WC. Autotransplantation for treatment of severe splenic lesions. Emerg Radiol. 2002;9(4):208-12.

11. Petroianu A, Petroianu Larissa PG. Splenic autotransplantation for treatment of portal hypertension. J Can Chir. 2005;48:382-386.

12. Cothren CC, Moore EE, Biffl WL, Ray CE, Ciesla DJ, Johnson JL. Radiographic characteristics of postinjury splenic autotransplantation: avoiding a diagnostic dilemma. J Trauma. 2004;57(3):537-41.

13. Weber T, Hanisch E, Baum RP, Seufert RM. Late results of heterotopic autotransplantation of splenic tissue into the greater omentum. World J Surg. 1998;22(8):883-9.

14. Teixeira Brandt C, Maciel DT, Caneca OAF, De Castro Machado Célia Maria, 
De Araújo Bragante L. Autotransplant of spleen tissue in children with schistosomiasis: evaluation of splenic function after splenosis. Mem Inst Oswaldo Cruz. 2001;96 Suppl:117-22.

15. Ionescu NG, Cucu A, Szabo I, Mircea P, Cotul S, Bojan A. Autografting of the traumatized spleen. Rev Chir Oncol Radiol O R L Oftalmol Stomatol Chir. 1988;37(5):363-70. Romanian

16. Di Carlo I, Pulvirenti E, Toro A. A new technique for spleen autotransplantation. Surg Innov. 2012;19(2):156-61

17. Cardoso DL, Cardoso Filho FA, Cardoso AL, Gonzaga ML, Grande AJ. Should splenic autotransplantation be considered after total splenectomy due to trauma? Rev. Col. Bras. Cir. 2018; 45(3):e1850

18. Seicaru T, Micale R. Actualitati în patologia chirurgicala a splinei. În Proca E. (coord.) Actualitati în chirurgie. Editura Medicala; 1983. p. 257-263.

19. Traub A, Giebink GS, Smith C, Kuni CC, Brekke ML, Edlund D, et al. Splenic reticuloendothelial function after splenectomy, spleen repair, and spleen autotransplantation. N Engl J Med. 1987;317(25):1559-64.

20. Teixeira RKC, Santiago LA, Sasaki YA, Yamaki VN, Feijó DH, Brito MVH, Yasojima EY, Petroianu A. Influence of splenic implants in the subcutaneous tissue on asplenic animals survival. Arq Bras Cir Dig. 2018;31(2):e1364.

21. Surendran A, Smith M, Houli N, Usatoff V, Spelman D, Choi J. Splenic autotransplantation: a systematic review. ANZ J. Surg. 2019 Oct 2. [Epub ahead of print].

22. Marques RG, Petroianu A, Coelho JMC de 0. Bacterial Phagocytosis by Macrophage of Autogenous Splenic Implant. Braz J Biol. 2003;63(3):491-5.

23. Lucas C.E. Splenic Trauma-Choice of Management. Ann. Surg. 1991; 213: 98-112. Ann Surg. 1991;213(2):98-112.

24. Tzoracoleftherakis E, Alivizatos V, Kalfarentzos F, Androulakis J Complications of splenic tissue reimplantation. Ann R Coll Surg Engl. 1991; 73(2):83-6

25. Toro A, Parrinello NL, Schembari E, Mannino M, Corsale G, Triolo A, et al. Single segment of spleen autotransplantation, after splenectomy for trauma, can restore splenic functions. World J Emerg Surg. 2020;15(1):17.

26. Corazza GR, Tarozzi C, Vaira D, Frisoni M, Gasbarrini G. Return of splenic function after splenectomy: how much tissue is needed? Br Med J (Clin Res Ed). 1984;289(6449):861-4.

27. Chiotoroiu AL, Venter DM, Negoi I, Vartosu C, Plotogea 0, Paun S, Vartic M, Beuran M. Splenic implant assessment in trauma. Chirurgia (Bucur). 2014;109(6):731-40.

28. Soltani E, Aliakbarian M, Ghaffarzadegan K. Which common test should be used to assess spleen autotransplant effect? Ulus Travma Acil Cerrahi Derg. 2018;24(1):16-19

29. Cucu A, Ionescu NG, Szabó I, Mircea P, Cotul S. Functionalitatea grefonului în autotransplantul splenic. Al XVI-lea Congres National de Chirurgie. Mamaia; 15-18 Mai 1991: 244-245. Volum de rezumate.

30. Khorshidi HR, Kasraianfard A, Ghaderzadeh P, Javadi SMR, Sharifi A, Makarchian HR, et al. Auto-transplantation of splenic fragments after total splenectomy in patients with severe splenic trauma lesions: a clinical study. Trauma Mon. 2018;23(5):e63242.

31. Pabst R, Kamran D. Autotransplantation of splenic tissue. J Pediatr Surg. 1986;21(2):120-4

32. Lüdtke FE, Mack SC, Schuff-Werner P, Voth E. Splenic function after splenectomy for trauma. Role of autotransplantation and splenosis. Acta Chir Scand. 1989;155(10):533-9.

33. Cooney DR, Dearth JC, Swanson SE, Dewanjee MK, Telander RL. Relative merits of partial splenectomy, splenic reimplantation, and immunization in preventing postsplenectomy infection. Surgery. 1979:86(4):561-9.

34. Holdsworth RJ. Regeneration of the spleen and splenic autotransplantation.
Br J Surg. 1991;78(3):270-8

35. Willführ KU, Westermann J, Pabst R. Splenic autotransplantation provides protection against fatal sepsis in young but not in old rats. J Pediatr Surg. 1992;27(9):1207-12.

36. Petroianu A, da Silva RG, Nascimento Cardoso V, Alberti LR, da Silva MG. Effect of spleen surgeries on Escherichia coli distribution on the mononuclear phagocytic system. Int J Surg. 2010;8(1):48-51.

37. Bauer M, Aigner K, Schwemmle K, Wolf H. Should splenic tissue be reimplanted after splenectomy due to birth trauma? Monatsschr Kinderheilkd. 1982;130(8):630-631.

38. Henneking K, Müller C, Franke F, Becker H, Schwemmle K. Spätergebnisse der heterotopen Autotransplantation von Milzgewebe nach traumatischer Milzruptur im Kindesalter [Follow-up of heterotopic autotransplantation of splenic tissue after traumatic splenic rupture in childhood]. Chirurg. 1994; 65(5):457-68. German.

39. Holdsworth RJ, Irving AD, Cuschieri A. Postsplenectomy sepsis and its mortality rate: actual versus perceived risks. Br J Surg. 1991;78(9):1031-8.

40. Moore GE, Stevens RE, Moore EE, Aragon GE. Failure of splenic implants to protect against fatal postsplenectomy infection. Am J Surg. 1983;146(3):413-4.

41. Rowell SE, Biffl WL, Brasel K, Moore EE, Albrecht RA, DeMoya M, et al. Western Trauma Association Critical Decisions in Trauma: Management of adult blunt splenic trauma-2016 updates. J Trauma Acute Care Surg. 2017; 82(4):787-793

42. Toro A, Mannino M, Reale G, Di Carlo I: Splenic autotransplantation in a patient with human immunodeficiency virus infection: a case report. J Med Case Reports. 2011:5:379.

43. Roy P, Mukherjee R, Parik M. Splenic trauma in the twenty-first century: changing trends in management [published online ahead of print, 2018 Aug 16]. Ann R Coll Surg Engl. 2018;100(8):1-7.

44. Zandvoort $A$, Timens $W$. The dual function of the splenic marginal zone: essential for initiation of anti-TI-2 responses but also vital in the general first-line defense against blood-borne antigens. Clin Exp Immunol. 2002; 130(1):4-11.

45. Resende V, Petroianu A. Estudo funcional tardio do auto-implante esplênico após trauma complexo do baço humano. Late functional study of human spleen autotransplantation after severe splenic injuries. Revista do Colégio Brasileiro de Cirurgiões. 2001;28(3):167-172.

46. Marques RG, Petroianu A, Coelho JMCO, Portela MC. Regeneration of splenic implants. Ann Hematol. 2002;81:622-626. Ann Hematol. 2002; 81(11):622-6.

47. Shatz DV, Schinsky MF, Pais LB, Romero-Steiner S, Kirton OC, Carlone GM Immune responses of splenectomized trauma patients to the 23-valent pneumococcal polysaccharide vaccine at 1 versus 7 versus 14 days after splenectomy. J Trauma. 1998;44(5):760-5; discussion 765-6.

48. Palmiere C, Tettamanti C, Scarpelli MP, Tse R. The forensic spleen: Morphological, radiological, and toxicological investigations. Forensic Sci Int. 2018;291:94-99.

49. Zamfir T, Raducanu Gh, lacob OC, Patrancus T, Dinu F, Stavila A. Rupturile traumatice de splina la copil. XVIII-Rezumatele lucrarilor prezentate la Congresul National de Chirurgie. Chirurgia. XLIV (numar special); 1995.

50. Lee H, Kang BH, Kwon J, Lee JC-J. Splenic autotransplantation after blunt spleen injury in children. J Trauma Inj 2018;31(2):87-90.

51. Jakob H, Lustenberger T, Schneidmüller D, Sander AL, Walcher F, Marzi I. Pediatric Polytrauma Management. Eur J Trauma Emerg Surg. 2010; 36(4): 325-38

52. Ionescu G, Szabó I. Leziunie traumatice ale splinei. În Ionescu NG (coord.) Splina. Cluj-Napoca: Ed. Dacia; 1993. p. 160-188. 